\section{Tolerance of Three Sweet Corn Hybrids to a Postemergence Tankmix of Nicosulfuron plus Bromoxynil}

\author{
Cheryl-Ann L. Corbett and Nader Soltani ${ }^{1}$ \\ Ridgetown College, University of Guelph, Ridgetown, ON, Canada NOP 2CO
}

Allan S. Hamill

Agriculture and Agri-Food Canada Agriculture and Agri-Food Canada, Harrow, ON, Canada NOR $1 G 0$

Peter H. Sikkema, Stephen Bowley, and Darren E. Robinson

Department of Plant Agriculture, University of Guelph, ON, Canada NG1 2W1

Additional index words. bromoxynil, nicosulfuron, sweet corn, synergism

\begin{abstract}
Trials were conducted over 2 years at three locations in Ontario to determine the tolerance of three sweet corn hybrids to postemergence application of nicosulfuron (25 and $\left.50 \mathrm{~g} \cdot \mathrm{ha}^{-1}\right)$, bromoxynil $\left(280\right.$ and $\left.560 \mathrm{~g} \cdot \mathrm{ha}^{-1}\right)$, and nicosulfuron plus bromoxynil $\left(25+280 \mathrm{~g} \cdot \mathrm{ha}^{-1}\right.$ and $\left.50+560 \mathrm{~g} \cdot \mathrm{ha}^{-1}\right)$. All hybrids showed injury 7 days after treatment (DAT). The crop largely recovered from the injury in most treatments, as indicated by the ratings completed 14 and 28 DAT. However injury from the tankmix of nicosulfuron plus bromoxynil at both rates still appeared to be synergistic at 7, 14, and 28 DAT. Visual injury, height reductions and yield loss in the nicosulfuron plus bromoxynil $\left(50+560 \mathrm{~g} \cdot \mathrm{ha}^{-1}\right)$ treatment were more severe than in the other herbicide treatments. Yield of BSS5362 was significantly decreased in the nicosulfuron $\left(50 \mathrm{~g} \cdot \mathrm{ha}^{-1}\right)$ and nicosulfuron plus bromoxynil $\left(50+560 \mathrm{~g} \cdot \mathrm{ha}^{-1}\right)$ but was not affected by any other herbicide-hybrid combination. Caution must be exercised when using this tankmix combination, as there is potential to cause significant visual injury, height reductions and yield loss.
\end{abstract}

Sweet corn is the second largest vegetable crop in Ontario in terms of farm value (Mailvaganam, 2004). Sweet corn seedlings are not very vigorous and the crop is more susceptible to injury from herbicides and from weed competition-induced yield reductions than field corn (Robinson et al., 1993). There are no postemergence herbicide tankmix options for the control of both broadleaf and grass weeds in sweet corn in Ontario. Many weed management programs in sweet corn contain atrazine. High rates of atrazine may cause excessive injury in susceptible rotational crops and may also result in groundwater contamination. Lower rates of atrazine can minimize these risks but may also result in decreased weed control performance (Ontario Ministry of Agriculture and Food, 2004). Additionally, many weed species have evolved triazineresistant biotypes which cannot be controlled with atrazine (Heap, 2004).

Nicosulfuron is a sulfonylurea herbicide. Sulfonylurea herbicides provide control of susceptible species by inhibiting the ALS enzyme. These herbicides have a more favorable environmental profile than atrazine because they are active at low doses, have low potential for groundwater contamination, and have low mammalian toxicity. Nicosulfuron controls many annual grass weeds (Dobbels and Kapusta, 1993; DuPont, 2003), quackgrass

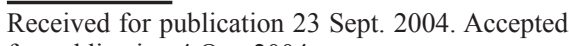
for publication 4 Oct. 2004.

${ }^{1}$ To whom all correspondence should be addressed; e-mailnsoltani@ridgetownc.uoguelph.ca.
[Agropyron repens (L.) Beauv.] (DuPont, 2003) as well as redroot pigweed (Amaranthus retroflexus) and Pennsylvania smartweed (Polygonum pensylvanicum L.) (Kapusta et al. 1994). Nicosulfuron must be tankmixed with a broadleaf herbicide to provide effective broad-spectrum weed control (Dobbels and Kapusta, 1993).

Sweet corn hybrids exhibit differential tolerance to nicosulfuron. Some hybrids are completely tolerant while others are extremely sensitive (Grey et al., 2000; Morton and Harvey 1992; O’Sullivan et al., 2000; Robinson et al., 1993, 1994; Stall and Bewick 1992). O'Sullivan and Bouw (1998) and O'Sullivan et al. (1995) observed significant injury to some sweet corn hybrids (notably Delmonte 2038, Merit, and Silver Extra Sweet) when nicosulfuron-rimsulfuron was applied at 25 or $50 \mathrm{~g} \cdot \mathrm{ha}^{-1}$.

Tolerant sweet corn hybrids are able to metabolize the parent herbicide to a less-phytotoxic metabolite (Burton et al., 1994, as cited in Grey et al., 2000). Symptoms of susceptible hybrids include reduced stalk height (Williams and Harvey, 1996), reduced vigor (Morton and
Harvey, 1992), reduced marketable yield (Stall and Bewick, 1992), and decreased leaf number (Robinson et al., 1994). Nicosulfuron injury is often greater when sweet corn is treated with an organophosphorus insecticide (eg terbufos) as both pesticides are metabolized by the same metabolic pathway (Stall and Bewick, 1992; Williams and Harvey, 1996).

Bromoxynil is a nitrile herbicide that inhibits PSII. The site of action of bromoxynil is different from that of atrazine, and most weed populations that are resistant to atrazine remain susceptible to bromoxynil. Bromoxynil is a contact herbicide that can cause temporary crop injury (leaf scorching). Injury from bromoxynil is more likely to occur when the herbicide is applied under adverse growing conditions such as cool and wet or hot and humid weather (Bayer CropScience, 2002). Corn injury is increased when bromoxynil is applied in a tankmix with nicosulfuron/rimsulfuron. This injury can be minimized by applying the herbicides sequentially with at least 12 $\mathrm{h}$ between applications (Bayer CropScience, 2002). Injury from bromoxynil does not appear to be restricted to particular hybrids.

Nicosulfuron plus bromoxynil is a registered tankmix for all hybrids offield corn grown in Ontario (DuPont, 2003), but no studies have examined the effects of the tankmix of nicosulfuron plus bromoxynil on sweet corn. A one-pass application of nicosulfuron plus bromoxynil would be a useful broad-spectrum, postemergence treatment if it were registered in sweet corn. The objective of this study was to determine the tolerance of three different sweet corn hybrids to a postemergence tank mix of nicosulfuron plus bromoxynil at once and twice the label rates for field corn.

\section{Materials and methods}

This study was conducted at the Huron Research Station, Exeter, Ont., in 2002 and 2003, at Ridgetown College, Ridgetown, Ont., in 2002 and 2003, and at the Greenhouse and Processing Crop Research Centre, Harrow, Ont., in 2003. Soil characteristics for each site and year are indicated in Table 1. The experiment was a split-plot design with four replications (each main plot measuring $2.25 \times$ $10 \mathrm{~m}$ ) and three hybrids (FTF246, BSS5362, and CNS710R). The main plot was herbicide treatment, and subplots were sweet corn hybrid (one hybrid row per subplot).

Dates of planting and emergence for each year and location are summarized in Table 2. The sweet corn was overseeded and thinned to a uniform population of 50,000 plants/ha. The sweet corn hybrids tested (BSS5362, CNS710, and FTF246) were chosen because

Table 1. Soil characteristics at Exeter, Ridgetown, and Harrow, Ont., in 2002 and 2003.

\begin{tabular}{lllccccc}
\hline & & & \multicolumn{4}{c}{ Soil texture (\%) } \\
\cline { 4 - 7 } Site & Year & Soil class & $\mathrm{pH}$ & Organic matter & Sand & Silt & Clay \\
\hline Exeter & 2002 & Clay loam & 8.0 & 4.5 & 26 & 37 & 37 \\
& 2003 & Perth Clay Loam & 7.7 & 4.0 & 23 & 47 & 30 \\
\multirow{2}{*}{ Ridgetown } & 2002 & Loam & 5.9 & 6.0 & 46 & 29 & 25 \\
& 2003 & Loam & 7.2 & 9.2 & 49 & 34 & 17 \\
Harrow & 2003 & Fox Sandy Loam & 6.6 & 2.6 & 82 & 5 & 13 \\
\hline
\end{tabular}


Table 2. Summary of planting and application dates at Exeter, Ridgetown, and Harrow, Ont., in 2002 and 2003.

\begin{tabular}{lcccc}
\hline Site & Year & Planting date & Emergence date & Application date \\
\hline Exeter & 2002 & 23 May & 1 June & 18 June \\
\multirow{2}{*}{ Ridgetown } & 2003 & 3 June & 13 June & 24 June \\
& 2002 & 22 May & 3 June & 12 June \\
Harrow & 2003 & 5 June & 11 June & 24 June \\
\hline
\end{tabular}

they were among the most popular processing hybrids grown in Ontario. The experimental plots were maintained weed free by applying $S$-metolachlor-benoxacor-atrazine at 2.16 $\mathrm{kg} \cdot \mathrm{ha}^{-1}$ a.i. immediately after planting and by cultivation and hand weeding.

Treatments at Exeter and Ridgetown were applied with a $\mathrm{CO}_{2}$ pressurized backpack sprayer with XR8002VS flat fan nozzles at $200 \mathrm{~L} \cdot \mathrm{ha}^{-1}$, at 241 and $207 \mathrm{kPa}$, respectively. At Harrow, treatments were applied with a $\mathrm{CO}_{2}$ pressurized backpack sprayer at $210 \mathrm{kPa}$ with XR11003VS flat fan nozzles at $200 \mathrm{~L} \cdot \mathrm{ha}^{-1}$. All applications were made postemergence (POST) to sweet corn at the three to five leaf stage (see Table 2). The treatments were nicosulfuron at $25 \mathrm{~g} \cdot \mathrm{ha}^{-1}$ with $0.2 \%$ Agral $90 \mathrm{v} / \mathrm{v}$, nicosulfuron at $50 \mathrm{~g} \cdot \mathrm{ha}^{-1}$ with Agral 90 at $0.4 \%$ $\mathrm{v} / \mathrm{v}$, bromoxynil at $280 \mathrm{~g} \cdot \mathrm{ha}^{-1}$, bromoxynil at $560 \mathrm{~g} \cdot \mathrm{ha}^{-1}$, nicosulfuron at $25 \mathrm{~g} \cdot \mathrm{ha}^{-1}$ with Agral 90 at $0.2 \% \mathrm{v} / \mathrm{v}$ plus bromoxynil at $280 \mathrm{~g} \cdot \mathrm{ha}^{-1}$, and nicosulfuron at $50 \mathrm{~g} \cdot \mathrm{ha}^{-1}$ with Agral 90 at $0.4 \% \mathrm{v} / \mathrm{v}$ plus bromoxynil at $560 \mathrm{~g} \cdot \mathrm{ha}^{-1}$.

Crop injury was assessed 7,14 , and 28 DAT by a visual evaluation of symptoms. A rating of 0 was assigned to plots with no visible effects and a rating of 100 was assigned to plots with complete plant mortality. Plant height from five randomly selected corn plants was recorded 21 DAT. Height was measured from the soil surface to the highest point of each corn plant with the leaves fully extended. The entire row of sweet corn in each plot was harvested at maturity.

All data were subjected to analysis of variance. Tests were combined over locations and years and analyzed using the PROC MIXED procedure of SAS (version 8, SAS Institute Inc., Cary, N.C.). Variances were partitioned into the fixed effects of herbicide treatment, hybrid, and herbicide $\times$ hybrid interaction and into the random effects of test, block(test), test $\times$ treatment, test $\times$ hybrid and test $\times$ hybrid $\times$ treatment. Significance of random effects was tested using a $\mathrm{Z}$ test of the variance estimate and fixed effects were tested using $F$ tests. Error assumptions of the variance analyses (random, homogeneous, normal distribution of error) were confirmed using residual plots and the Shapiro-Wilk normality test. To meet assumptions of the variance analysis, percent injury at 7, 14, and 28 DAT were subjected to an arcsine square root transformation (Bartlett 1947). Treatment means were separated using Fisher's protected LSD. The Type I error was set at 0.05 for all statistical comparisons.

\section{Results and Discussion}

Visual injury. Tests offixed effects indicated that there was an interaction between hybrid and herbicide for visual injury 7, 14, and 28
DAT indicating a difference in response for these three hybrids to the herbicide treatments evaluated (Table 3 ).

BSS5362. All herbicide rates and combinations caused injury to BSS5362 at 7, 14, and 28 DAT except for the $1 \times$ rate of bromoxynil at 14 DAT (Tables 4, 5, and 6). Visual injury 7 DAT from the $1 \times$ rate of nicosulfuron was $6 \%$, and injury from the $1 \times$ rate of bromoxynil was $4 \%$, but crop injury from the tankmix application of both herbicides at their $1 \times$ rates was $13 \%$. Crop injury from the $2 \times$ rate of nicosulfuron was $13 \%$, and injury from the $2 \times$ rate of bromoxynil was $6 \%$, but crop injury from the tankmix application of both herbicides at their $2 \times$ rates was $23 \%$. These results are indicative of a synergistic rather than additive effect when bromoxynil and nicosulfuron are applied as a tankmix.

CNS710R. CNS710R was the most tolerant hybrid in terms of percent injury 7 or 14 DAT (Tables 4 and 5). At 7 DAT, CNS710R was not affected by nicosulfuron at $1 \times$ or $2 \times$ or by bromoxynil at the $1 \times$ rate. Bromoxynil at the $2 \times$ rate caused a $4 \%$ injury, which was not different from the injury observed at the $1 \times$ rate of nicosulfuron plus bromoxynil. The greatest injury was observed at the $2 \times$ rate of nicosulfuron plus bromoxynil. The injury to this hybrid from both the $1 \times$ and $2 \times$ rates of nicosulfuron plus bromoxynil was synergistic in nature, as the injury from the combination was much greater than the injury from the individual herbicides added together. There was no injury to CNS710R at 14 DAT from any herbicide treatment except from the $2 \times$ rate of nicosulfuron plus bromoxynil (Table $5)$. This injury also was synergistic, as injury from the $2 \times$ rate of nicosulfuron and the $2 \times$ rate of bromoxynil were each $<1 \%$. CNS710R was

Table 3. Tests of fixed effects for herbicide treatment, sweet corn hybrid and treatment by hybrid interaction.

\begin{tabular}{lccccc}
\hline Effect & Day 7 & Day 14 & Day 28 & Ht & Yield \\
\hline Treatment & 0.0001 & 0.0001 & 0.0065 & 0.0001 & 0.3041 \\
Hybrid & 0.0025 & 0.0077 & 0.0062 & 0.0006 & 0.0106 \\
Treatment $\times$ hybrid & 0.0002 & 0.0006 & 0.0260 & 0.4108 & 0.0216 \\
\hline
\end{tabular}

Table 4. Mean percent injury to sweet corn hybrids $7 \mathrm{~d}$ after treatment with various postemergence herbicides. $^{\mathrm{z}}$

\begin{tabular}{|c|c|c|c|c|}
\hline \multirow{2}{*}{$\begin{array}{l}\text { Herbicide } \\
\text { treatment }\end{array}$} & \multirow{2}{*}{$\begin{array}{l}\text { Herbicide } \\
\text { rate } \\
\text { (g.ha- }{ }^{-1} \text { a.i.) }\end{array}$} & \multicolumn{3}{|c|}{ Hybrid (\%) } \\
\hline & & BSS5362 & CNS710R & FTF246 \\
\hline Check & 0 & $0 \mathrm{a}$ & $0 \mathrm{a}$ & $0 \mathrm{a}$ \\
\hline Nicosulfuron & 25 & $6 \mathrm{~b}$ & $0 \mathrm{a}$ & $0 \mathrm{ab}$ \\
\hline Nicosulfuron & 50 & $13 \mathrm{c}$ & $1 \mathrm{ab}$ & $3 \mathrm{bc}$ \\
\hline Bromoxynil & 280 & $4 \mathrm{~b}$ & $1 \mathrm{ab}$ & $3 \mathrm{bc}$ \\
\hline Bromoxynil & 560 & $6 \mathrm{~b}$ & $4 \mathrm{bc}$ & $5 \mathrm{c}$ \\
\hline Nicosulfuron plus Bromoxynil & $25+280$ & $13 \mathrm{c}$ & $5 \mathrm{c}$ & $7 \mathrm{c}$ \\
\hline Nicosulfuron plus Bromoxynil & $50+560$ & $23 \mathrm{~d}$ & $12 \mathrm{~d}$ & $15 \mathrm{~d}$ \\
\hline
\end{tabular}

${ }^{\mathrm{z}}$ Means presented have been back transformed to the original scale; means pressurizedfollowed by the same letter are not significantly different according to a Fisher's protected LSD test $(P \leq 0.05)$. 
BSS5362 showed more injury than FTF246 or CNS710R with all herbicide rates and herbicide combinations at all three assessment times. CNS710R was the least injured hybrid at 7 and 14 DAT, but it showed greater injury than FTF246 at 28 DAT. Both Grey et al. (2000) and O'Sullivan et al. (2000) found hybrid differences with regards to severity of injury among sweet corn cultivars.

Height. The test of fixed effects indicated that there was no interaction between treatment and hybrid for the parameter height, indicating that all hybrids responded similarly to the herbicides evaluated. The mean height of sweet corn 28 DAT was unaffected by either rate of nicosulfuron or bromoxynil, or the $1 \times$ rate of nicosulfuron plus bromoxynil (Table 7). A significant reduction in height from the untreated plots was observed at the $2 \times$ rate of nicosulfuron plus bromoxynil. Robinson et al. (1994) observed that POST applications of nicosulfuron at $35 \mathrm{~g} \cdot \mathrm{ha}^{-1}$ significantly decreased crop height in the hybrid 'Zenith' in 1991 but not 1993, attributing the decrease to greater environmental stresses (such as drought

or pest damage) in 1991 . At $15 \mathrm{~g} \cdot \mathrm{ha}^{-1}$ nicosulfuron, Grey et al. (2000) reported significant decreases in height for four of ten hybrids in 1992 but only two hybrids in 1993. They attributed this to herbicide application timing (15 cm in 1992 compared to $40 \mathrm{~cm}$ in 1993). In one location-year, O'Sullivan et al. (2000) observed that plant height decreased with increased nicosulfuron application (from 25 to $50 \mathrm{~g} \cdot \mathrm{ha}^{-1}$ ) in all eleven hybrids. At two other location-years, plant height was only reduced in five and three hybrids, respectively. Herbicide application was delayed at one location-year to the seven-leaf stage, which has been shown to increase nicosulfuron injury in several sweet corn hybrids (Robinson et al. 1993). However, the trends indicated in this research and in the research of O'Sullivan et al. (2000) indicate that the degree of plant stunting increases with increased nicosulfuron dose and is compounded by stressors such as application timing or additional xenobiotics (such as bromoxynil or certain insecticides) that are detoxified by metabolism (Morton et al., 1993; Williams and Harvey, 1996).

Table 5. Mean percent injury to sweet corn hybrids $14 \mathrm{~d}$ after treatment with various postemergence herbicides. $^{2}$

\begin{tabular}{|c|c|c|c|c|}
\hline \multirow{2}{*}{$\begin{array}{l}\text { Herbicide } \\
\text { treatment }\end{array}$} & \multirow{2}{*}{$\begin{array}{l}\text { Herbicide } \\
\text { rate } \\
\left.\text { (g.ha- }{ }^{-1} \text { a.i. }\right)\end{array}$} & \multicolumn{3}{|c|}{ Hybrid (\%) } \\
\hline & & BSS5362 & CNS710R & FTF246 \\
\hline Check & 0 & $0 \mathrm{a}$ & $0 \mathrm{a}$ & $0 \mathrm{a}$ \\
\hline Nicosulfuron & 25 & $4 \mathrm{bc}$ & $0 \mathrm{a}$ & $0 \mathrm{a}$ \\
\hline Nicosulfuron & 50 & $8 \mathrm{c}$ & $1 \mathrm{a}$ & $0 \mathrm{a}$ \\
\hline Bromoxynil & 280 & $1 \mathrm{ab}$ & $0 \mathrm{a}$ & $0 \mathrm{a}$ \\
\hline Bromoxynil & 560 & $2 \mathrm{~b}$ & $1 \mathrm{a}$ & $1 \mathrm{a}$ \\
\hline Nicosulfuron plus Bromoxynil & $25+280$ & $6 \mathrm{c}$ & $1 \mathrm{a}$ & $1 \mathrm{a}$ \\
\hline Nicosulfuron plus Bromoxynil & $50+560$ & $13 \mathrm{~d}$ & $5 \mathrm{~b}$ & $6 \mathrm{~b}$ \\
\hline
\end{tabular}

${ }^{2}$ Means presented have been back transformed to the original scale; means within a column followed by the same letter are not significantly different according to a Fisher's protected LSD test $(P \leq 0.05)$.

Table 6. Mean percent injury to sweet corn hybrids $28 \mathrm{~d}$ after treatment with various postemergence herbicides. $^{2}$

\begin{tabular}{|c|c|c|c|c|}
\hline \multirow{2}{*}{$\begin{array}{l}\text { Herbicide } \\
\text { treatment }\end{array}$} & \multirow{2}{*}{$\begin{array}{l}\text { Herbicide } \\
\text { rate } \\
\text { (g.ha }{ }^{-1} \text { a.i.) }\end{array}$} & \multicolumn{3}{|c|}{ Hybrid (\%) } \\
\hline & & BSS5362 & CNS710R & $\overline{\text { FTF246 }}$ \\
\hline Check & 0 & $0 \mathrm{a}$ & $0 \mathrm{a}$ & $0 \mathrm{a}$ \\
\hline Nicosulfuron & 25 & $1 \mathrm{~b}$ & $0 \mathrm{ab}$ & $0 \mathrm{a}$ \\
\hline Nicosulfuron & 50 & $5 \mathrm{~d}$ & $0 \mathrm{ab}$ & $0 \mathrm{a}$ \\
\hline Bromoxynil & 280 & $1 \mathrm{~b}$ & $1 \mathrm{ab}$ & $0 \mathrm{a}$ \\
\hline Bromoxynil & 560 & $1 \mathrm{~b}$ & $0 \mathrm{ab}$ & $0 \mathrm{a}$ \\
\hline Nicosulfuron plus Bromoxynil & $25+280$ & $2 \mathrm{c}$ & $1 \mathrm{bc}$ & $0 \mathrm{a}$ \\
\hline Nicosulfuron plus Bromoxynil & $50+560$ & $5 \mathrm{~d}$ & $3 \mathrm{c}$ & $1 \mathrm{a}$ \\
\hline
\end{tabular}

${ }^{\mathrm{z}}$ Means presented have been back transformed to the original scale; means within a column followed by the same letter are not significantly different according to a Fisher's protected LSD test $(P \leq 0.05)$.

Table 7. Height (28 d after treatment) and yield of sweet corn hybrids treated with various postemergence herbicides. $^{\mathrm{z}}$

\begin{tabular}{|c|c|c|c|c|c|}
\hline \multirow{2}{*}{$\begin{array}{l}\text { Herbicide } \\
\text { treatment }\end{array}$} & \multirow{2}{*}{$\begin{array}{l}\text { Herbicide } \\
\text { rate } \\
\text { (g.ha- }{ }^{-1} \text { a.i.) }\end{array}$} & \multirow{2}{*}{$\begin{array}{c}\text { Mean } \\
\mathrm{ht}^{\mathrm{y}} \\
(\mathrm{cm})\end{array}$} & \multicolumn{3}{|c|}{ Yield $\left(\mathrm{t} \cdot \mathrm{ha}^{-1}\right)$} \\
\hline & & & BSS5362 & CNS710R & FTF246 \\
\hline Check & 0 & $84 \mathrm{~b}$ & $18.9 \mathrm{~b}$ & $14.1 \mathrm{ab}$ & $17.1 \mathrm{a}$ \\
\hline Nicosulfuron & 25 & $84 \mathrm{~b}$ & $17.9 \mathrm{ab}$ & $14.3 \mathrm{ab}$ & $17.1 \mathrm{a}$ \\
\hline Nicosulfuron & 50 & $82 \mathrm{~b}$ & $17.3 \mathrm{a}$ & $15.0 \mathrm{~b}$ & $17.5 \mathrm{a}$ \\
\hline Bromoxynil & 280 & $85 \mathrm{~b}$ & $19.0 \mathrm{~b}$ & $14.5 \mathrm{ab}$ & $17.5 \mathrm{a}$ \\
\hline Bromoxynil & 560 & $81 \mathrm{~b}$ & $19.1 \mathrm{~b}$ & $14.4 \mathrm{ab}$ & $17.5 \mathrm{a}$ \\
\hline Nicosulfuron plus bromoxynil & $25+280$ & $82 \mathrm{~b}$ & $18.7 \mathrm{~b}$ & $14.1 \mathrm{ab}$ & $17.1 \mathrm{a}$ \\
\hline Nicosulfuron plus bromoxynil & $50+560$ & $74 \mathrm{a}$ & $16.6 \mathrm{a}$ & $13.5 \mathrm{a}$ & $17.7 \mathrm{a}$ \\
\hline $\operatorname{LSD}(0.05)$ & & 4 & 1.3 & 1.3 & 1.3 \\
\hline
\end{tabular}

${ }^{\mathrm{z}}$ Means within a column followed by the same letter are not significantly different according to a Fisher's protected LSD test $(P \leq 0.05)$.

${ }^{y}$ Heights have been averaged for BSS5362, CNS710, and FTF246 sweet corn hybrids.
Yield. A test of fixed effects indicated an interaction between treatment and hybrid for the parameter yield, indicating that there were differences in the way different hybrids responded to the herbicide treatments evaluated. The yield of FTF246 was unaffected by any herbicide treatment or rate (Table 7). There were no differences between the untreated control and any herbicide treatment in hybrid CNS710R, but there was a significant difference between the $2 \times$ rate of nicosulfuron and the $2 \times$ rate of nicosulfuron plus bromoxynil. In hybrid BSS5362, there was a decrease in yield when nicosulfuron or the tankmix of nicosulfuron plus bromoxynil were applied at the $2 \times$ rate. These yield data indicate that no yield losses occurred when nicosulfuron, bromoxynil, or nicosulfuron plus bromoxynil were used at the $1 \times$ rates in these three sweet corn hybrids. Dobbels and Kapusta (1993) observed that field corn yields were lower at one location when nicosulfuron was used alone rather than in combination with bromoxynil, but there was no difference at another location. They attributed the yield loss to a lack of common lamb's-quarters control by nicosulfuron alone at the location with decreased yield. The sweet corn plots in this study were treated with a preplant application of $S$-metolachlor-benoxacor-atrazine and then hand-weeded to eliminate weed competition to ensure that the results reflected yield loss due to herbicide injury rather than weed competition.

Significant yield loss only occurred at $2 \times$ nicosulfuron or $2 \times$ nicosulfuron plus bromoxynil in one hybrid (BSS5362). There was no yield loss from any herbicide treatment in two hybrids (CNS710R and FTF246). Grey et al. (2000) applied nicosulfuron at $15 \mathrm{~g} \cdot \mathrm{ha}^{-1}$ and found that only one of eleven hybrids had a decreased yield. Robinson et al. (1994) observed that POST applications of nicosulfuron at $35 \mathrm{~g} \cdot \mathrm{ha}^{-1}$ resulted in complete crop loss in one hybrid (Merit) in 1991 and 1993, a 50\% reduction in yield in another (Zenith) in 1991, but no reduction in yield in Zenith in 1993. O'Sullivan et al. (2000) observed complete yield loss in 'Delmonte 2038', no yield loss in some other hybrids, and moderate yield reductions in some hybrids that were more severe at $50 \mathrm{~g} \cdot \mathrm{ha}^{-1}$ nicosulfuron than at $25 \mathrm{~g} \cdot \mathrm{ha}^{-1}$. Stall and Bewick (1992) determined that four of twelve hybrids demonstrated a response to nicosulfuron rate whereby marketable yield was significantly lower at $72 \mathrm{~g} \cdot \mathrm{ha}^{-1}$ than at 18 $\mathrm{g} \cdot \mathrm{ha}^{-1}$. This body of evidence indicates that yield reduction in sweet corn in response to nicosulfuron application is both hybrid and rate dependant.

\section{Conclusions}

Injury to all three sweet corn hybrids by all herbicide treatments was transient, and all three hybrids had markedly improved by 28 DAT. Yield was not affected by herbicide treatment in two of three hybrids (CNS710R and FTF246), but BSS5362 exhibited a decrease in yield when treated with the $2 \times$ rate of nicosulfuron or the $2 \times$ rate of nicosulfuron plus bromoxynil. CNS710R and FTF246 are 
listed on the nicosulfuron label as tolerant to nicosulfuron whereas BSS5362 is not (DuPont, 2003). Bromoxynil is registered on all sweet corn hybrids. BSS5362 consistently had more severe injury and greater yield loss than the other two hybrids when treated with $1 \times$ or $2 \times$ rates of nicosulfuron plus bromoxynil. Hybrid yield response to either rate of nicosulfuron plus bromoxynil reflected the sensitivity of a particular hybrid to nicosulfuron and was not influenced by the addition of bromoxynil. Recommendations for hybrid tolerance to a postemergent tankmix of nicosulfuron plus bromoxynil should consider hybrid tolerance, though caution must be exercised as this tankmix combination has potential to cause significant visual injury, height reductions and yield loss.

\section{Literature Cited}

Bartlett, M.S. 1947. The use of transformations. Biometrics 3:39-52.

Bayer CropScience. 2002. Pardner ${ }^{\circledR}$ herbicide. Pt\# 120268 Label. Bayer CropScience. 13 Apr. 2004. www.bayercropscience.ca/products/attachments/Pardner_E.PDF.
Dobbels,A.F. and G. Kapusta. 1993. Postemergence weed control in corn (Zea mays) with nicosulfuron combinations. Weed Technol. 7:844-850

Dupont. 2003. Accent ${ }^{\circledR} 75$ DF herbicide. 25116 20030731-F2 E Label. Dupont Canada Inc. 13 Apr. 2004. www.dupont.ca/ag/uploads/P140L Accent $\% 20$ Herbicide.pdf.

Grey, T.L., D.C. Bridges, P. Raymer, D. Day, and D. Scott NeSmith. 2000. Differential tolerance of fresh market sweet corn cultivars to the herbicides nicosulfuron and primisulfuron. HortScience 35(6): 1070-1073

Heap, I. The international survey of herbicide resistant weeds. 8 Sept. 2004. www.weedscience. com.

Kapusta, G., R.F. Krausz, M. Khan, and J.L. Matthews. 1994. Effect of nicosulfuron rate, adjuvant and weed size on annual weed control in corn (Zea mays). Weed Technol. 8:696-702

Mailvaganam, S. 2004. Fresh market sales and sales to processors of specified commercial vegetable crops, Ontario, 2003. 13 Apr. 2004. www.gov. on.ca/OMAFRA/english/stats/hort/vegsale03. $\mathrm{html}$.

Morton, C.A., R.G. Harvey, J.J. Kells, D.A. Landis, W.E. Lueschen, and V.A. Fritz. 1993. In-Furrow Terbufos reduces field and sweet corn (Zea mays) tolerance to nicosulfuron. Weed Technol. 7:934-939
Ontario Ministry of Agriculture and Food. 2004 Guide to weed control 2004-2005. Publ. 75. Ont. Min. Agr. Food, Toronto.

O'Sullivan, J., R.A. Brammall, and W.J. Bouw. 1995. Response of sweet corn (Zea mays) cultivars to nicosulfuron plus rimsulfuron. Weed Technol. 9:58-62

O'Sullivan, J. and W.J. Bouw. 1998. Sensitivity of processing sweet corn (Zea mays) cultivars to nicosulfuron/rimsulfuron. Can. J. Plant Sci. 78:151-154

O'Sullivan, J.,P.H. Sikkema, and R.J. Thomas. 2000. Sweet corn (Zea mays) cultivar tolerance to nicosulfuron. Can. J. Plant Sci. 80:419-423

Robinson, D.K., D.W. Monks, and J.R. Schultheis. 1994. Effect of nicosulfuron applied postemergence and post-directed on sweet corn (Zea mays) tolerance. Weed Technol. 8:630-634

Robinson, D.K., D.W. Monks, J.R. Schultheis, and A.D. Worsham. 1993. Sweet corn (Zea mays) cultivar tolerance to application timing of nicosulfuron. Weed Technol. 7:840-843

Stall, W.M. and T.A. Bewick. 1992. Sweet corn cultivars respond differentially to the herbicide nicosulfuron. HortScience 27(2):131-133

Williams, B.J. and R.G. Harvey. 1996. Nicosulfuron tolerance in sweet corn (Zea mays) as affected by hybrid, rootworm insecticide, and nicosulfuron treatment. Weed Technol. 10:488-494 